\title{
The Role of Capacity Building in Public Service Delivery in Mogadishu-Somalia
}

\author{
Abdikariin Sheikh Mohamed Hassan* \\ Somalia \\ *Corresponding Author: Abdikariin Sheikh Mohamed Hassan, Somalia

\begin{abstract}
This study investigated the impact of capacity building in public service delivery in MogadishuSomalia. The study had three objectives a) to explore the relationship between capacity building and effective in Mogadishu municipality b) to identify the role of Mogadishu municipalities on capacity building programs. And c) to find out the influence of between capacity building and effective in Mogadishu municipality

This study used a survey research design conducted on 140 respondents of the local municipality of Mogadishu, Somalia. Data were analyzed in SPSS 16.

The key findings indicated that there is a significant positive correlation between training dimension and public service delivery is $r=0.169$, the correlation between seminar and public service delivery was found are $=0.257$ which indicates a significant positive correlation. While the last capacity building dimension workshop wasa $=0.413$ correlation on public service delivery. The result shows that the all dimensions of training, seminars, and workshop have a strong positive correlation with (DV) public service delivery. However, there is a relationship between training, seminars, workshop on public service delivery.
\end{abstract}

The researcher recommended the government and the community member should be in a forefront in providing street children with attachments, resources and opportunities to develop skills

Key words: capacity building, Public Service Delivary, Training, Seminars, local Government, Workshop, Human Resource.

\section{INTRODUCTION AND BACKGROUND OF THE STUDY}

Capacity building is often to cover human recourse development and strengthen of the managerial system, institutional development that involves community participation and creation of an enabling environment. Capacity building through training seminars and workshops usually help to ensure that local government workers possess right knowledge and skill that equip them to ensure effective public service delivery to the people at the grass root or beneficiaries .(Chukwudi, 2015)

In Africa as a crucial responsibility of government and government institutions, the public service should deliver those who lives government jurisdictions, it is services that a society requires to maintain and improve its welfare. To do this, government institutions require organizational structures and suitably qualified people who must be supported to deliver the services they are responsible for (Whitaker, 1980).

Besley and Ghatak (2007) argue that public services are delivered by a nexus of relationships between beneficiaries, politicians and service providers (such as bureaucrats, doctors, and teachers). They insist that it is necessary to analyze the incentives that govern the behavior of politicians and service providers, if services are to match the best interest of the beneficiaries. The authors further argue that the main concern in public service provision is how the obligations of the different parties is defined and enforced. Public services should be concerned with what customers want rather than what providers are prepared to give. Yet in most of the developing countries public service delivery is characteristic of ineffective, cumbersome, too procedural, costly, red taped and not transparent systems. Tamrakar (2010) further argues that generally, public servants have acted as masters without any sense of accountability and transparency instead of acting as servants of the people. However, the citizens have become familiarized to the enhanced service delivery from the private sector and thus, they now view the public sector as another provider of services for which they pay taxes(Matei \& Camelia, 2015) 
In the Somalia context public service delivery was large consensus that Somalia faces many of the challenges that affect in the people because lack of sustainable capacity building and training. Therefore, this study was investigated the capacity building and public service delivery in Mogadishu local government

This study developed toward an integrative theory of training, motivation developed by (Tannenbaum \& Yukl, 1992). Following Kanfer (1991), we were defined training, motivation here as the direction, intensity, and persistence of learning-directed behavior in training contexts. This research has sought to understand the effect of training improving capacity building and public service civil effectiveness and its outcome to an individual beneficiary (Ngure, 2013).

Literal meaning "Capacity can be defined as the ability of individuals and organizations or organizational units to perform functions effectively, efficiently and sustainably." This definition has three important aspects: it indicates that capacity is not a passive state, but is part of a continuing process; it ensures that human resources and the way in which they are utilized are central to capacity development; and it requires that the overall context within which organizations undertake their functions was also be a key consideration in strategies for capacity development. In this UNDP was publicized, capacity is seen as two-dimensional:(Enemark \& Wasiamson, n.d.)

Nwankwo et al.Capacity as the capability of a person, an institution or organization to perform a given task effectively, efficiently and on a continuing basis and with reduced dependence on external resources. Capacity building is therefore concerned with Human resource development (people), institutional development (Local government system) and the overall policy environment within which the local governments (as public service organizations) operate and interact. Capacity building can also help to determine the efficient utilization and allocation of human resources among competing Demand. Simply and generally defined, therefore, capacity building Implies activities which strengthen the knowledge, abilities, skills and behavior of individuals and improve institutional structures and processes such that the organization can efficiently meet its mission and goals in a sustainable way (Sci, Aff, Vincent, \& Stephen, 2015) Azikwiwe (2006) defines capacity building as the process by which and individual, irrespective of sex, are equipped with skill and knowledge need to perform with skill and knowledge they need to perform effectively and efficient in have led to investment in education which in turn raises rural income ancis, \& Abubakar, 2013).

Laterally means the public services delivery are not physical resources but economic transactions exchanged for money, comprising of the exchange of specialized skill and knowledge. He further insists that goods constitute tangible materializations of knowledge and activities and thus are nothing more than distributional mechanisms for services.(Sunday et al., 2013)Seems describe public service delivery to be of the same opinion when he defines services as intangible activities performed by machines or persons or both for the purposes of creating value perceptions among customers. He further stresses that since services delivery are intangible activities or benefits produced by the service provider and in association with the consumer, their quality results in the perception and value assessment of the consumer. (Sunday et al., 2013).

Edvards son and Olsson (1996) refer to the service concept as the prototype for service and define it as the detailed description of what is to be done for the customer, i.e. what needs and wishes are to be satisfied, and how this is to be achieved(Sunday et al., 2013).

In the context of Somalia recently in our best knowledge, there was a lack of capacity building, including not having training, seminars and workshops, caused to poorly affected public service delivery. Therefore, this study was investigated the impact of capacity building in public service delivery in Mogadishu-Somalia

\section{Problem Statement}

Capacity building is a key strategy for achieving public service delivery and the main objective is to provide high quality life to the population in a clean and secure environment by transforming the country into a newly implemented key public service delivery and initiatives to create an efficient and more productive public service delivery. Many public organizations have now adopted employee capacity building as a means of improving the quality, efficiency and speed of public service delivery (Ngure \& Njiru, 2013). 
In Somalia as a crucial responsibility of government and government institutions, public service delivery is characteristic of ineffective, cumbersome, too procedural, costly, red taped and not transparent systems. Generally, public servants have acted as masters without any sense of accountability and transparency instead of acting as servants of the people (Tamrakar, 2010)

Therefore, there is a need to investigate the relationship between the capacity building and public service delivery in Mogadishu-municipality.

\section{MeThodology}

\section{Research Population}

The target populations for this study will be conducted among Mogadishu municipality workers and the accessible populations 215 of service, unit employees of Mogadishu municipality cited from the deputy director of labor (Nour ages abdulle,2016)

\section{Research Design}

This study will establish causal relationship between variables so researcher attempt explanatory research design with emphasis on studying a situation or a problem in order to explain the relationships between capacity building and public service delivers in Mogadishu municipality. Also the descriptive research design will be considered appropriate for this study as it allowed description of a phenomena as well as a collection of data from a sizable population.

The main purpose of the survey is to show the exact relationship between the independent and dependent variable by using a cross-sectional survey to get quantifiable data to answer the research questions.

\section{Sample size}

The researchers used Solvent's formula to calculate the sample size, with maximum acceptable error $5 \%$. $\mathrm{n}$

$\mathrm{N}$ : Stands the population

n. Stands the sample

a. Stands acceptable error

$\mathrm{n}=140$

$=$ The sample sizes of the unit servants 140, the Researchers were distributed questionnaires to departmental units and total of questionnaires was 140.

Table1. The target population of the study

\begin{tabular}{|l|l|l|l|}
\hline No & Target Population & Population & Sample \\
\hline 1 & Tax department & 42 & 28 \\
\hline 2 & Human resource department & 42 & 28 \\
\hline 3 & Planning and development department & 42 & 28 \\
\hline 4 & Registration and birth department & 42 & 28 \\
\hline 5 & Sanitation department & 42 & 28 \\
\hline Total & 210 & 140 \\
\hline
\end{tabular}

\section{Research Instrument}

This study will use a questionnaire as research instrument of data collection from every respondent. The main objective of the questionnaire is to collect a lot of information in short periods of time. Because they are suitable if a population is large and time is limited, the selecting of this survey will guide by the nature of the data to be collected; the researcher will select this method because it was given the researcher opportunities to meet face to face with respondents and was explaining the purpose of this study. Also the researcher will help them to fill the questionnaires to collect quantitative data from the selected respondents. Therefore the structure of this questionnaire was two parts, first part was be 9 questions and another one consist of 9 questions which make at total of 18 questions which states the following scales such as 1-strongly agree 2- Agree 3-neutral 4-disagree 5strongly disagree 


\section{Ethical Consideration}

The researcher was attempted to keep ethics by with regard to and preserving of the respondents' information. To keep the ethical issue data given by the respondent will be used only for academic purpose, however this researcher was respect to maintain individual self-confidence

\section{FINDINGS AND DISCUSIONS}

\subsection{Demographic Data}

This section presents the background information of the respondents who participated in the study. The purpose of this background information is to find out the characteristics of respondents and shows the distribution of the population is the study.

\subsection{Demographic Analysis}

Table2. Gender

\begin{tabular}{|l|l|l|}
\hline Variable & Frequency & Percentage \\
\hline Male & 90 & $64.3 \%$ \\
\hline Female & 50 & $35.7 \%$ \\
\hline Total & $\mathbf{1 4 0}$ & $\mathbf{1 0 0 \%}$ \\
\hline
\end{tabular}

Table 1 shows the demographic characteristics of respondents. Total of the respondents of this study was 140 workers in Mogadishu municipality institutions Benadir-Somalia. In terms of gender 90 out of 140 was male, which means $64.3 \%$, while 60 of respondents was female out the total which means $35.7 \%$. According to this result the workers of media institutions dominated by male.

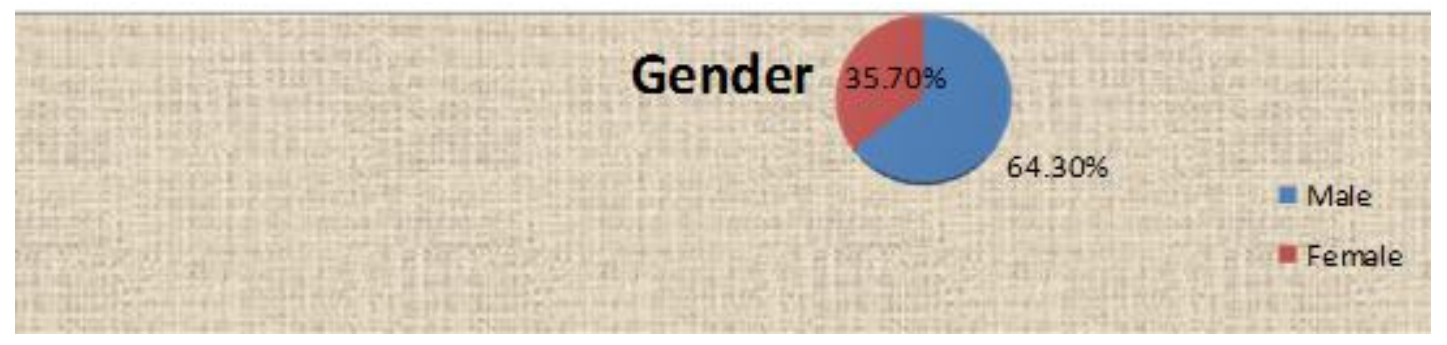

Figure1. Gender

Table3. Marital status

\begin{tabular}{|l|l|l|}
\hline Variable & Frequency & Percentage \\
\hline Single & 59 & $55.7 \%$ \\
\hline Married & 62 & $44.8 \%$ \\
\hline Divorced & 19 & $13.6 \%$ \\
\hline Total & $\mathbf{1 4 0}$ & $\mathbf{1 0 0 \%}$ \\
\hline
\end{tabular}

Table 2 depicts the marital status of respondents. The table illustrates that $55.7 \%$ of the respondents were single and $44.8 \%$ were married while the majority of $13.6 \%$ of the respondents were divorced.

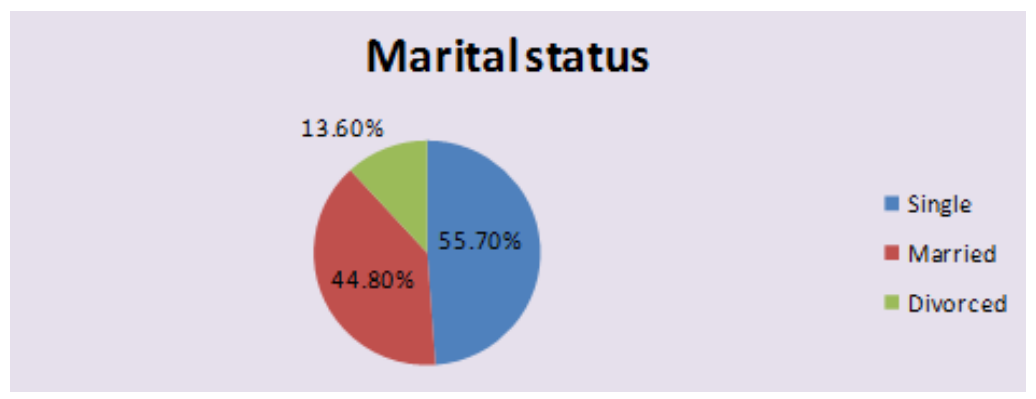

Figure2. Marital status

Table4. Age

\begin{tabular}{|c|l|l|}
\hline Variable & Frequency & Percentage \\
\hline $20-25$ & 52 & $55.7 \%$ \\
\hline $26-30$ & 62 & $44.8 \%$ \\
\hline $30-40$ & 19 & $13.6 \%$ \\
\hline
\end{tabular}


The Role of Capacity Building in Public Service Delivery in Mogadishu-Somalia

\begin{tabular}{|l|l|l|}
\hline 40 above & 3 & $2.1 \%$ \\
\hline Total & $\mathbf{1 4 0}$ & $\mathbf{1 0 0 \%}$ \\
\hline
\end{tabular}

In the age group of this study was categorized into four groups such: - 52 of the respondents their age between 20-25 which means $37.1 \%$. Also the age 60 of respondents lies $25-30$ of the total of respondents on average is $42.9 \%$. The age 25 of the respondents was between $30-40$, in percentage is equivalent $17.9 \%$. Lastly, the remaining respondent's age 3 was above 40 years which means $2.1 \%$. According the age groups of the Mogadishu municipality mostly their age lies 25-30 years.

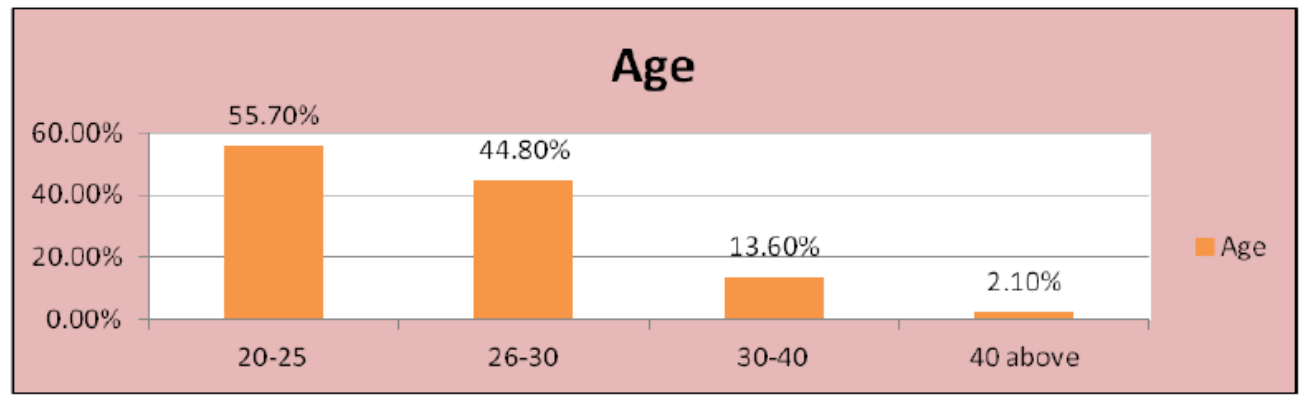

Figure3. Age

Table5. Educational level

\begin{tabular}{|l|l|l|}
\hline Variable & Frequency & Percentage \\
\hline Secondary & 29 & $20.7 \%$ \\
\hline Bachelor & 84 & $60 \%$ \\
\hline Master & 24 & $17.1 \%$ \\
\hline PhD & 3 & $2.1 \%$ \\
\hline Total & $\mathbf{1 4 0}$ & $\mathbf{1 0 0 \%}$ \\
\hline
\end{tabular}

This result shows $42.9 \%$ of Mogadishu municipality's personnel are youth. In terms of qualification $60 \%$ of the respondents were bachelors, $17.1 \%$ were mastered, $20.7 \%$ were secondary and $2.1 \%$ were $\mathrm{PhD}$.

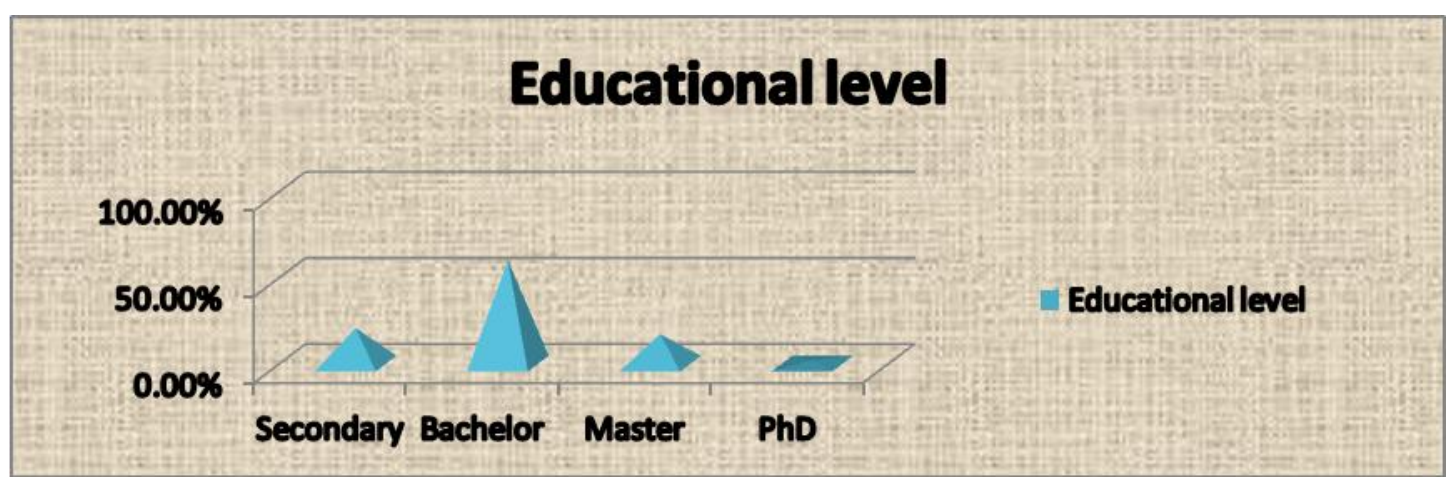

Figure4. Educational level

Table6. Experience

\begin{tabular}{|l|l|l|}
\hline Variable & Frequency & Percentage \\
\hline Less than 2yrs & 25 & $17.86 \%$ \\
\hline 2-4 years & 88 & $62.86 \%$ \\
\hline 4-6 years & 22 & $15.71 \%$ \\
\hline 6-10 years & 5 & $3.57 \%$ \\
\hline Total & $\mathbf{1 4 0}$ & $\mathbf{1 0 0 \%}$ \\
\hline
\end{tabular}

Experience

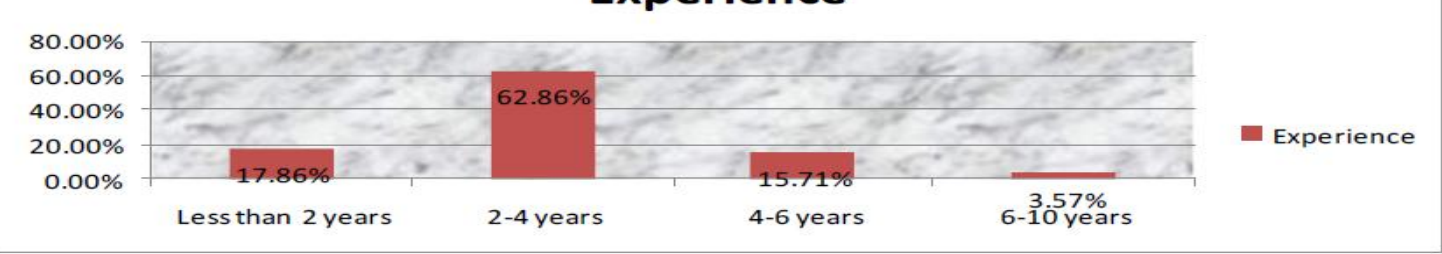

Figure1. Experience 


\section{Data PRESEntation AND ANALysis}

After background information, the researchers went ahead to present the descriptive analysis from the opinions of the respondents. The researchers selected based on Mogadishu municipality, the result from this sample can be generalize to all Somalia local governments.

Table1. Descriptive for capacity building Items

\begin{tabular}{|l|l|l|l|l|}
\hline No & Items & Mean & SD & Response \\
\hline 1 & $\begin{array}{l}\text { Training directly contributes to increased personnel's ability in Benadir } \\
\text { municipality }\end{array}$ & 1.43 & .750 & $\begin{array}{l}\text { Strongly } \\
\text { Agree }\end{array}$ \\
\hline 2 & $\begin{array}{l}\text { Training is a major contributor of an employee's knowledge and } \\
\text { development in Benadir municipality }\end{array}$ & 1.89 & .987 & Agree \\
\hline 3 & training improves the standard activities of personnel in local area & 1.96 & .995 & Agree \\
\hline 4 & Valuable resource of knowledge at current is a seminar & 2.24 & 1.156 & Agree \\
\hline 5 & Interchange experiences increase the outcome of employee & 2.20 & 1.276 & Agree \\
\hline 6 & \begin{tabular}{l} 
Seminar excites employee for their regular activities \\
\hline 7
\end{tabular} & 2.14 & 1.339 & Agree \\
\hline & Promoting the potential technique in blender municipality is important & 2.18 & 1.152 & Agree \\
\hline 8 & $\begin{array}{l}\text { Lack of workshop on base work there is no significance, potential of } \\
\text { employee to fit their job }\end{array}$ & 2.41 & 1.330 & Agree \\
\hline 9 & \multicolumn{1}{|c|}{ Average Mean } & $\mathbf{2 . 0 9}$ & $\mathbf{1 . 2 3}$ & Agree \\
\hline & & & Agree \\
\hline
\end{tabular}

The above table 5 presented the mean index, Standard deviation, and interpretation of the result of the all questions asked of the respondents with the Independent variable (IV), researcher was analysis here the interpretation of the respondent's answers. So far, the first question has mean index 1.34 and Stander deviation 0.75 which shows that respondents denoted that they are Strongly Agree in this question.

The second question obtained mean 1.89, standard deviation of 0.987 and interpretations of this question ware Agree.

The third question has 1.96 mean index and standard deviation 0.995 for interpreting that they agree for this question.

The mean index for 4th question was 2.24; standard deviation of 1.156 and the respondents denotes agree in this question.

The 5th question was scored mean 2.20 and standard deviation of 1.176 in according of the interpretation respondents denotes agree.

The $6^{\text {th }}$ question obtained mean 2.14, standard deviation of 1.339 and interpretation of this question ware agree.

The $7^{\text {th }}$ question has 2.18 mean index and standard deviation 1.152 for interpreting that they response for agreeing with this question.

The mean index for $8^{\text {th }}$ question was 2.29 ; standard deviation of 1.171 and the respondents denotes agree in this question.

The $9^{\text {th }}$ question was scored mean 2.41 and standard deviation of 1.330 in according of the interpretation respondents denotes agree.

The final Average means index of the all questions was 2.02, Standard deviation was $\mathbf{1 . 2 3}$ and respondents were agree for their average answers 
Table2. Descriptive for public service delivery

\begin{tabular}{|c|c|c|c|c|}
\hline No & Items & Mean & SD & Response \\
\hline 1 & potential for achieving result is the effectiveness & 1.86 & 1.026 & Agree \\
\hline 2 & $\begin{array}{l}\text { the degree to which something obtain in human capacity of } \\
\text { investing them going to reach the goal }\end{array}$ & 2.17 & .967 & Agree \\
\hline 3 & $\begin{array}{l}\text { Powerful use of things and time to worth position for the } \\
\text { purpose of gaining against it paid }\end{array}$ & 2.24 & 1.124 & Agree \\
\hline 4 & $\begin{array}{l}\text { Public organizations are able to service provision to meet } \\
\text { the needs of the diverse groups of citizens that they serve }\end{array}$ & 1.81 & .944 & Agree \\
\hline 5 & $\begin{array}{l}\text { The extent to which citizens perceive the service provided } \\
\text { by local government to be distributed in this way we want }\end{array}$ & 2.39 & 1.050 & Agree \\
\hline 6 & The best way to increase justice and finding the properties & 1.96 & 1.208 & Agree \\
\hline 7 & $\begin{array}{l}\text { responding local needs of society can increase service } \\
\text { performance }\end{array}$ & 1.88 & 1.076 & Agree \\
\hline 8 & $\begin{array}{l}\text { ability that governance as whole contributes by creating } \\
\text { new jobs and training opportunity for people in need }\end{array}$ & 2.16 & 1.152 & Agree \\
\hline 9 & $\begin{array}{l}\text { Local governance responsiveness allow people to increase } \\
\text { the satisfaction in local areas }\end{array}$ & 2.44 & 1.260 & Agree \\
\hline & Average mean & 2.10 & 1.09 & \\
\hline
\end{tabular}

The above table 6 presented the mean index, Santander deviation, and interpretation of the result with the all question asked for the respondent for the Dependent Variable (DV), and researchers, ware analysis here the interpretation of the respondent's answers. So far, the first question has mean index 1.86 and Stander deviation 1.026 which shows that respondents denoted that they are Agree in this question. The second question obtained mean 2.17, standard deviation of .967and interpretation of this question ware Agree. The third question has 2.24 mean index and standard deviation 1.124 for interpreting that they agree for this question. The mean index for 4th question was 1.81; standard deviation of .944 and the respondents denotes Disagree in this question. The 5th question was scored mean 2.39 and standard deviation of 1.050 in according of the interpretation respondents denotes agree. The $6^{\text {th }}$ question obtained mean 1.96, standard deviation of 1.208 and interpretation of this question ware agree. The $7^{\text {th }}$ question has 1.88 mean index and standard deviation. 1.076 For interpreting that they response for agree in this question. The mean index for $8^{\text {th }}$ question was 2.16 ; standard deviation of 1.152and the respondents denotes agrees in this question. Therefore the final Average means index of the all questions was 2.26, Standard deviation was 1.25 and respondents ware Agree for their average answers.

Table1. correlation between independent and dependent variables

\begin{tabular}{|l|l|l|l|l|}
\hline Variables & Training & Seminar & Workshop & Public service \\
\hline Training & 1 & $.280^{* *}$ & .125 & $.169^{*}$ \\
\hline Seminar & $.280^{* *}$ & 1 & $.181^{*}$ & $.257^{* *}$ \\
\hline Workshop & .125 & $.181^{*}$ & 1 & $.413^{* *}$ \\
\hline Public service & $.169^{*}$ & $.257^{* *}$ & $.413^{* *}$ & 1 \\
\hline
\end{tabular}

**. Correlation is significant at the 0.01 level (2-tailed).

\subsection{Correlation Between Variables}

The objective of this study was to determine the relationship between training, seminar, workshop and public service delivery in Mogadishu municipality. The correlation between training, seminar, workshop and public service as shown in the table is 0.839 Which means level of training, seminar and workshop may cause a average of $83.9 \%$ of increasing public service, thereby there is a strong positive relationship between training, seminar, workshop and public service delivery $(r=.839$, $\mathrm{p}<0.000)$.

Table2. Regression analysis

\begin{tabular}{|l|l|l|l|}
\hline \multirow{2}{*}{ Variable } & \multicolumn{2}{|l|}{ Public Service Delivery } & Significance \\
\cline { 2 - 4 } & Beta & T & .348 \\
\hline Training & .075 & .941 & .000 \\
\hline Seminar & .169 & 2.099 & .000 \\
\hline Workshop & .373 & 4.802 & \\
\hline
\end{tabular}




\section{CONCLUSION}

Most of the researches have concluded that capacity building has a positive effect on the public service delivery. This makes capacity building as the most important aspect of any organization setup and creating an environment which facilitates and supports employee to perform optimally. Today's pubic organization requires organizations to be more creative and innovative which cannot happen without having a committed and loyal employee base The success of every organization depends upon many factors but the most important factor that affects is training its employees. If the employees of an organization are well trained towards organizational objective, the organization can achieve its goals very easily.

So, if the local government institutions in Mogadishu-Somalia get a fully trained, they can curb administrative perform in Mogadishu municipality.

The researcher also described the effect of seminar on service delivery in Mogadishu-Somalia. The study discovers that a strong positive correlation between seminar and service delivery. If the capacity building gets seminar immediately, they can express the service delivery made by the local governmental institutions thus productivity git.

If the capacity building gets the power to be empowered the local governmental institutions, they was to be able to increase citizen service delivery.

\section{REFERENCES}

[1] CLARK, D. C. (1991). CAPACITY MANAGEMENT IN SERVICES. Cranfield Institute of Technology.

[2] Davis-Cooper, M. G. (2014). Capacity Building and Developmental Outcomes in Two English- Caribbean Countries. GSTF International Journal of Psychology.

[3] Fledderus, J. A. (2015). Building trust through public service. International Journal of Public Sector Management.

[4] Gekonde, T. (2014). A STUDY ON THE INFLUENCE OF STRATEGIC HUMAN RESOURCE AND ORGANIZATIONAL CAPACITY BUILDING ON PERFORMANCE IMPROVEMENT OF PUBLIC SERVICE DELIVERY IN NAKURU COUNTY-KENYA. Global Journal of Political Science and Administration.

[5] Jha, S. (2013). Empowerment and Public Service Delivery in. RESEARCHGATE.

\section{AUTHOR'S BIOGRAPHY}

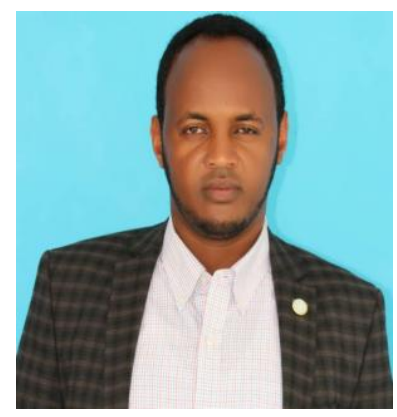

Dr. Abdikarin Sheikh Mohamed Hassan, is currently a Rector of Horseed International University, He obtained his $\mathrm{PhD}$ from International Astrolable University, Turkey and participated in several community activities in the Country. In addition to his academic career, Dr Abdikariin held several managerial positions in the academic field.

Citation: Abdikariin Sheikh Mohamed Hassan. "The Role of Capacity Building in Public Service Delivery in Mogadishu-Somalia" International Journal of Humanities Social Sciences and Education (IJHSSE), vol 7, no. 6, 2020, pp. 67-74. doi: http://dx.doi.org/10.20431/2349-0381.0706008.

Copyright: (C) 2020 Authors. This is an open-access article distributed under the terms of the Creative Commons Attribution License, which permits unrestricted use, distribution, and reproduction in any medium, provided the original author and source are credited. 